\title{
CEO innovation orientation and R\&D intensity in small and medium-sized firms: the moderating role of firm growth
}

\author{
Nils D. Kraiczy • Andreas Hack • \\ Franz W. Kellermanns
}

Published online: 21 November 2014

(c) Springer-Verlag Berlin Heidelberg 2014

\begin{abstract}
Although upper echelon literature has found evidence for the effect of executives' characteristics on firm strategy such as the level of research and development (R\&D) intensity, research on how different behaviors, values, personalities, motivations, and experiences of executives influence the R\&D intensity of small and medium-sized firms is scarce. Applying upper echelon theory, this study uses firm growth (sales and employee growth) as a contingency factor to analyze variations in the effect of chief executive officer (CEO) innovation orientation on R\&D intensity in small and medium-sized firms. As research on the direct effect of firm growth on R\&D intensity is inconclusive, this study applies firm growth as an indirect effect to show whether the impact of CEO innovation orientation on R\&D intensity differs in times of low growth compared to times of high growth in small and medium-sized firms. Using a sample of 77 German CEOs of small and medium-sized firms operating in manufacturing industries, results show that CEO innovation orientation has a positive effect on R\&D intensity, and firm growth affects this relationship. Specifically, high CEO innovation orientation has a
\end{abstract}

N. D. Kraiczy $(\square) \cdot$ A. Hack

Institute of Organization and Human Resource Management, University of Bern, Engehaldenstrasse 4, 3012 Bern, Switzerland

e-mail: nils.kraiczy@iop.unibe.ch

A. Hack

Witten Institute for Family Business, Witten/Herdecke University, Alfred-Herrhausenstr.

50, 58448 Witten, Germany

F. W. Kellermanns

Department of Management, University of North Carolina - Charlotte, 9201 University City Blvd, Charlotte 28223-0001, NC, USA

F. W. Kellermanns

Institute of Family Businesses, WHU - Otto Beisheim School of Management, Burgplatz 2, 56179 Vallendar, Germany 
positive effect on R\&D intensity in firms with low growth, while its impact disappears in firms that experience strong growth. Implications and future research are discussed.

Keywords CEO innovation orientation $\cdot R \& D$ intensity $\cdot$ Firm growth $\cdot$ Small and medium-sized firms

JEL Classification $\mathrm{M} 10 \cdot \mathrm{L} 2 \cdot \mathrm{O} 32$

\section{Introduction}

Small and medium-sized firms are considered to be the main driving force behind economic and employment growth in European countries (European Commission 2010). Their growth is crucial to ensuring firm survival and to improving economic development in their countries (Lotti et al. 2009). Among other antecedents of firm growth, research and development (R\&D) intensity has been identified as an important driver of firm growth (Nunes et al. 2012). However, path dependencies are not fully clarified. While much research has examined the effect of R\&D investment/intensity on firm growth (e.g., Filatotchev and Piesse 2009; García-Manjón and RomeroMerino 2012; Ho et al. 2006; Mudambi and Swift 2011), little research has focused on the influence of prior firm growth on $R \& D$ investment. Utilizing insights from the demand and opportunity cost literature, research on the relationship between firm growth and R\&D intensity has produced conflicting empirical findings (Aghion et al. 2005; Arvanitis and Woerter 2011; Barlevy 2007). While some studies show a positive effect between firm growth in terms of sales and employment and R\&D intensity (Coad and Rao 2009; Guellec and Ioannidis 1999; Hundley et al. 1996; Mairesse et al. 1999), others report a negative effect (Greve 2003; Hitt and Tyler 1991).

Research on the impact of firm growth on R\&D intensity has attracted a substantial amount of attention (Baysinger and Hoskisson 1989; Chen and Miller 2007; Falk 2012) that has focused on environmental (context) factors, in particular, economic cycles (Arvanitis and Woerter 2011; Barlevy 2007). Most expenditure invested in R\&D is financed through a firm's cash flows (Aghion et al. 2004; Himmelberg and Petersen 1994). Hence, resource restrictions have been shown to affect R\&D intensity levels. While high-growth firms should have sufficient free cash flow to invest more into $R \& D, R \& D$ intensity may decrease with falling demand (demand aspect). Due to financial constraints resulting from lower demand during a downturn or crisis (Campello et al. 2010), the demand aspect supports growth-dependent (pro-cyclical) investment behavior in terms of R\&D intensity. Empirical studies support this argument (e.g., Antonelli 1989; Guellec and Ioannidis 1999; Hundley et al. 1996; Kamien and Schwartz 1982; Mairesse et al. 1999).

Conversely, research also suggests a countercyclical effect between firm growth and $\mathrm{R} \& \mathrm{D}$ intensity. One argument, the opportunity cost argument, assumes that during a crisis/recession, R\&D activities are less expensive (more attractive) because opportunity costs are lower (Aghion and Howitt 1998; Arvanitis and 
Woerter 2011). To achieve higher profitability by introducing new products when markets are growing and are more receptive (Geroski and Gregg 1997), highly innovative, medium, and large firms, particularly in highly developed countries such as Germany, Sweden, and Switzerland, invest in R\&D (innovation) during a crisis (Filippetti and Archibugi 2011). Additionally, one may argue that high-growth firms may have already reached their optimal investment level in R\&D; therefore they decide not to invest more in R\&D but instead invest in other growth related measures (e.g., mergers and acquisitions, internationalization, marketing, human resource management). As a last argument, low-growth firms may need to invest more in $\mathrm{R} \& \mathrm{D}$ because their current low-growth is a consequence of a prior misalignment with market needs that must be rectified.

In this research stream, variations in $R \& D$ intensity have been investigated mainly from an industry perspective (Arvanitis and Woerter 2011; Thompson 2001), which under-estimates internal firm-level factors such as the impact of the chief executive officer (CEO) on decision making (e.g., Hambrick and Mason 1984). Hence, more research on the impact of the CEO and his/her role in the context of R\&D intensity is necessary to understand how innovation in organizations can be fostered (Felekoglu and Moultrie 2014; Souitaris 2001). In this context, firm growth may have a moderating effect rather than a direct effect on the relationship between CEO innovation orientation, which describes a behavioral intention of a CEO to engage in innovative activities, and R\&D intensity. Although small and medium-sized firms represent the majority of innovative behavior (European Commission 2013) and are critical for understanding entrepreneurship (Acs et al. 1999; Schumpeter 1934), research on this topic is under-researched in the field of small business economics, as recent studies have focused mainly on large publicly traded companies (e.g., Chen and Miller 2007; Muñoz-Bullón and Sanchez-Bueno 2011).

Our focus on small and medium-sized firms allows us to better isolate the impact of decisions by the CEO to invest in R\&D. We draw from upper echelon theory (Hambrick 2005, 2007; Hambrick and Mason 1984) to explain variations in the relationship between CEO innovation orientation and R\&D intensity by applying firm growth (sales and employee growth) as a moderator. Specifically, we argue that firm growth serves as a key contingency in this relationship.

Our study makes several contributions to the literature. First, by applying upper echelon theory, we introduce CEO innovation orientation to the nomological network of $R \& D$ research in small and medium-sized firms to emphasize the importance of the CEO when analyzing R\&D intensity. By doing so, we apply a firm-internal perspective to overcome shortcomings of studies that focus mostly on environmental factors. Second, by introducing firm growth as a moderator of this relationship, we reconcile the complex and contradictory findings in the literature on the direct effect of firm growth on R\&D intensity. Third, by focusing on small and medium-sized firms where hierarchies are often flat and managerial discretion of the CEO is often higher than in large publicly traded firms, we extend and contribute to recent research that focuses on R\&D in small and medium-sized firms (Falk 2012; Hall et al. 2009; Hölzl 2009; Ortega-Argilés et al. 2009). 
This paper is organized as follows. First, we describe upper echelon theory to show the importance of the CEO in small and medium-sized firms and his/her innovation orientation for the level of $R \& D$ intensity. We then introduce firm growth as a contingency factor that may affect the relationship between CEO innovation orientation and R\&D intensity. After presenting our results, we conclude by discussing theoretical implications and offering suggestions for future research.

\section{Theoretical framework and hypotheses}

\subsection{Upper echelon theory}

Upper echelon theory, as developed by Hambrick and Mason (1984), suggests that upper echelons, in particular, the CEO and the top management team (TMT) (Crossland and Hambrick 2007), are the most powerful individuals in the organization and thus have a strong impact on strategic choices and, in turn, firm outcomes. Upper echelon theory is an information processing theory that explains how executives act under conditions of bounded rationality. Based on their interpretation of situations, upper echelons make decisions that are influenced by each member's experience, personality, and values. Their personalized interpretations of situations directly affect their behaviors and strategic choices. Specifically, Hambrick and Mason (1984, p. 193) describe "organizations as the reflection of its top managers".

Although upper echelon literature has found evidence for the effect of CEO characteristics, in particular demographic characteristics, on firm performance (Carpenter et al. 2004; Hambrick 2005), research on how different CEO behaviors, values, personalities, motivations, and experiences influence the performance of small and medium-sized firms is scarce (Hambrick 2007; Lawrence 1997). Recent research has started to focus on the impact of the CEO and the TMT in small and medium-sized firms. For example, Kraiczy et al. (2014c) analyze CEO risk-taking propensity in small and medium-sized family firms, which refers to the willingness of a CEO to commit significant resources to exploit opportunities or to engage in behaviors with uncertain outcomes (Gilley et al. 2002; Keh et al. 2002). Additionally, their results show a positive effect of CEO risk-taking propensity on new product portfolio innovativeness. Compared to large publicly traded firms, CEOs of small and medium-sized firms may have an even stronger effect on strategic choices and firm outcomes. Indeed, CEO managerial discretion tends to be higher, as supervisory boards are less common (Ford 1988; Huse 2000), firms are closely held and owner-managed (Bennedsen and Wolfenzon 2000; Brunninge et al. 2007), and TMT size is often smaller than in large publicly traded companies. Furthermore, CEOs essentially determine and shape firm strategy; they are powerful decision makers who set the climate of the firm through their leadership style, goals, attitudes, and behaviors (Miller and Dröge 1986; Miller and Toulouse 1986b). In these firms, CEOs are often more involved in operational tasks and maintain direct personal contact with lower management levels. Additionally, compared with large 
companies, these firms often have informal strategies that are largely driven by the CEO.

Assuming that CEOs will have a stronger impact in small and medium-sized firms than in larger firms, CEO innovation orientation will likely influence R\&D intensity.

\subsection{CEO innovation orientation and R\&D intensity}

From an upper echelon perspective, the impact of CEOs on R\&D intensity is undisputed in large firms. However, Barker and Mueller (2002, p. 782) state that surprisingly "little has been done to examine the association of CEO characteristics with $R \& D$ spending". Using a behavioral approach, we introduce CEO innovation orientation as an antecedent of R\&D intensity. Prior research that has investigated the influence of upper echelons on $R \& D$ intensity has focused on large publicly traded and multi-product firms (Barker and Mueller 2002; Baysinger and Hoskisson 1989; Hoskisson and Hitt 1988) and has shown that CEOs can have a significant impact on R\&D spending (e.g., Barker and Mueller 2002; Daellenbach et al. 1999). In this study, we analyze innovation orientation as an individual behavior of the CEO instead of other characteristics such as entrepreneurial orientation (Rauch et al. 2009) or openness to new experiences (Nadkarni and Herrmann 2010) to explicitly focus on innovation-related behavior of the CEO. Hence, CEO innovation orientation refers to the behavioral intentions of CEOs to engage in innovative activities. The decision of the CEO regarding whether to increase or decrease R\&D intensity is fundamental because it determines the future performance of the firm and can lead to a competitive advantage (Ettlie 1998; Scherer 1984).

Research demonstrates that firm-level innovation orientation, both directly and indirectly, affects innovation outcomes (Calantone et al. 2003; Hurley and Hult 1998; Narver et al. 2004). For example, Narver et al. (2004) show a direct and positive impact of innovation orientation on new product performance. Similarly, Rosenbusch et al. (2011, p. 1) conclude that "fostering an innovation orientation has more positive effects on firm performance than creating innovation process outcomes such as patents or innovative products or services". Analyzing innovation orientation on the TMT-level, Kraiczy et al. (2014a) support a positive effect of TMT innovation orientation on new product portfolio performance. By transferring innovation orientation from the level of the firm and the TMT to that of the CEO, we suggest that innovation-oriented CEOs will invest more in R\&D to foster innovation. As the CEO's behavior is decisive and his/her managerial discretion is high in small and medium-sized firms, CEO innovation orientation will have a strong impact on R\&D intensity. In accordance with this, we hypothesize:

H1 CEO innovation orientation has a positive impact on R\&D intensity.

\subsection{Firm growth as a contingency factor}

Because the direct relationship of firm growth on R\&D intensity is complex and causality is not clear, we use firm growth as a moderating variable of the 
relationship between CEO innovation orientation and $R \& D$ intensity to analyze whether firm growth affects the impact of CEO innovation orientation on R\&D intensity. Specifically, we are interested in understanding whether different levels of firm growth influence the impact of CEO innovation orientation on R\&D intensity in small and medium-sized firms.

Applying upper echelon theory, low firm growth may further strengthen the positive effect of CEO innovation orientation on R\&D intensity. As lower firm growth can be perceived as a challenge for the CEO, job demands increase for the CEO. Hambrick et al. (2005) have introduced executive job demands that aim to differentiate between more and less difficult jobs. Hambrick et al. (2005, p. 472) define job demands as "the degree of challenge a given executive experiences in his or her job". Depending on the pressure, executives are exposed to different job demands. These variations are claimed to moderate the relationship between managerial characteristics and strategic choices. Job demands determine the degree that managerial characteristics will become reflected in the firm's strategic choices and performance (Hambrick 2007; Hambrick et al. 2005). In situations where executives are under high job demands, the time to make decisions is often limited. This leads to decisions being based on executives' backgrounds and experiences, which, in turn, become reflected in organizational outcomes. By contrast, minimal job demands provide more time for analyses and decision-making, which, in turn, generates sophisticated decisions. These decisions will be based on objective conditions more than on the personal backgrounds and experiences of executives. Hence, the effect of a CEO innovation orientation on R\&D intensity will be stronger when firm growth is low as job demands increase due to higher task and performance challenges. Furthermore, CEOs with a high innovation orientation may invest more in $\mathrm{R} \& \mathrm{D}$ to oppose the challenge of low firm growth by aiming to develop innovations.

Additionally, arguments from threat rigidity theory, which suggest that threats result in rigidity (Greve 2011), support a stronger effect of CEO innovation orientation on R\&D intensity when firm growth is low. In general, threat rigidity theory predicts that threats have a negative impact on the likelihood of managers to foster change (Staw et al. 1981). Common reactions in threat situations are psychological stress and anxiety, as well as physiological arousal, which lead to restrictions in information processing and constriction in control (Staw et al. 1981). When faced with threats, CEOs rely on well-learned and authoritative decisions, which result in more conservative strategies and behaviors (e.g., efficiency measures, tighter budgets, downsizing, cost cutting, productivity improvement, and diversification) (Ahmadjian and Robinson 2001; Anand and Singh 1997; Greve 2011). In the context of R\&D investments, which represent uncertain outcomes (Lee and O'Neill 2003), firms faced with low firm growth resulting from low market growth (threat) are more likely to reduce R\&D investments and related risks, leading to decreased $R \& D$ intensity. In particular, risk-averse individuals are described to be more strongly affected by the threat rigidity effect. As CEO innovation orientation is a risk-related behavioral intention towards innovation, CEOs showing higher levels of innovation orientation may be less risk averse and the effect of threats leading to rigidity may be lower. 
Hence, R\&D intensity levels should be more pronounced for CEOs with high innovation orientation when firm growth is low. In situations with low growth rates, CEOs with high innovation orientation will likely invest more in R\&D because they believe that these investments are important for the firm's future. CEOs with low innovation orientation will likely invest less in $\mathrm{R} \& \mathrm{D}$, as they are more conservative toward innovation or may use other strategies to react to low firm growth (e.g., introduction of existing products on new markets).

Summarizing, in situations with low growth rates, the CEO is confronted with a threat and job demands are higher. In these situations, CEO characteristics will become stronger reflected in strategic decisions. Accordingly, we hypothesize:

H2 The relationship between CEO innovation orientation and R\&D intensity is moderated by firm growth. Specifically, the lower the firm growth, the stronger the positive effect of CEO innovation orientation on R\&D intensity.

\section{Analysis}

\subsection{Sample}

Recent research on $\mathrm{R} \& \mathrm{D}$ intensity has mainly focused on large publicly traded companies (e.g., Chen and Miller 2007; Muñoz-Bullón and Sanchez-Bueno 2011). In Germany, small and medium-sized companies represent $99.7 \%$ of all businesses, produce $38 \%$ of taxable turnover, account for nearly $49 \%$ of total net value added by companies, and provide approximately 60 percent of all jobs requiring social insurance contributions (German Federal Ministry of Economics and Technology 2013). Despite their importance to the economy, research on the R\&D intensity of small and medium-sized firms is scarce in the management literature. Because most small and medium-sized German firms are not publicly traded, they are not required to report information such as R\&D expenditure (Hülsbeck et al. 2012), which makes research relying on databases virtually impossible.

To test our hypotheses, we collected data, as a part of a larger study (Kraiczy et al. 2014a, b, c), from CEOs of German small and medium-sized firms in four different manufacturing industries (industry 1: manufacturing of machinery, equipment, and motor vehicles; industry 2: manufacturing of chemicals, chemical, rubber, and plastic products; industry 3: other manufacturing industries; industry 4: manufacturing of basic metals); these industries were chosen for their high potential for R\&D investment. The representation of firms by industry is as follows: manufacturing of machinery and vehicles (Industry 1, $30 \%$ ); manufacturing of chemicals, chemical, rubber, and plastic products (Industry 2, $18 \%$ ); and manufacturing of basic metals (Industry 4, $36 \%$ ). The remaining firms operate in other industries (Industry 3, $16 \%$ ). We drew firm contacts from a database of the Southwestfalian Chamber of Commerce and Industry (Hagen, Germany) and chose a random sample of 1,000 firms with 50-499 employees. We specifically focused on small and medium-sized firms because the influence of CEOs affects firm outcomes more strongly than in large companies with complex organizational structures 
(Wright and Kellermanns 2011). We identified CEOs and their personal email addresses by scanning firm websites and the Markus database (a product of the German credit agency Creditreform), which contains comprehensive information on over 1.3 million companies in Germany, Austria, and Luxembourg.

We sent a personalized email to the CEO of each firm that included a link to our online questionnaire survey. Two weeks after the first contact, we sent out reminder emails followed by personal phone calls. In total, we received 77 responses. The response rate of $7.7 \%$ may be due to the privacy concerns and inward orientation of small and medium-sized firms (Upton et al. 2001; Zahra et al. 2004) and because CEOs of such firms are likely to be more involved in operational tasks and have little time to respond to surveys. Mean firm size is 169.19 employees; mean firm age is 67.43 years; mean CEO age is 47.87 years; and mean CEO tenure is 11.21 years. As CEOs are considered reliable key informants (Kumar et al. 1993; Seidler 1974), key informant bias is not a significant concern in this study.

We tested for multicollinearity issues by assessing the correlation matrix, the variance inflation factor (VIF), and the condition index (CI). Levels of correlations between the variables are modest. All VIFs $(<1.601)$ show acceptable values well below the suggested critical limit (Hair et al. 2010). The CIs $(<19.250)$ are also below the critical values suggested by Hair et al. (2010). Hence, we assume that multicollinearity is not a significant concern.

Because we collected our data via a single questionnaire, we tested for potential common method bias, as suggested by Podsakoff and Organ (1986). We entered all items of the control, moderator, independent, and dependent variables into a onefactor analysis and identified five factors with eigenvalues $>1.0$ that account for $76.76 \%$ of the variance. The first factor accounts for $18.74 \%$ of the variance, while the remaining factors account for $58.02 \%$. Because no single method factor emerged and the factors separated cleanly, we believe that common method bias is not a concern. Furthermore, the literature suggests that common method bias cannot affect the significance of interaction effects (Evans 1985).

We assessed potential non-response bias by comparing early and late respondents via a one-way ANOVA (analysis of variance), an approach that assumes that nonrespondents tend to be more similar to late respondents (Kanuk and Berenson 1975; Oppenheim 1966). As there are no significant differences between the two groups, we conclude that non-response bias is not a concern.

\subsection{Measures}

When possible, we used validated and reliable measurement scales based on measures of related constructs in the literature.

\subsubsection{CEO innovation orientation}

To measure CEO innovation orientation, we adapted eight items from an innovation climate scale originally developed by Scott and Bruce (1994) and based on the work of Siegel and Kaemmerer (1978). We modified the items to use them on an individual level. Responses were made on a five-point Likert-type scale, ranging 
from "not at all" to "to an exceptional degree". Reliability analysis shows a good internal consistency of the measure, with a Cronbach's alpha of 0.91. All item-tototal correlations exceed the suggested 0.50 cut-off. Exploratory factor analysis (varimax rotation) shows that all items loaded on one factor (eigenvalue $=5.04$ ); factor loadings ranged from 0.87 to 0.63 . The one factor explains 62.93 percent of the variance. Communalities range from 0.76 to 0.40 and show good results. Confirmatory factor analysis for the items of CEO innovation orientation shows an acceptable fit: normed fit index $=0.953$, comparative fit index $=0.993$, and root mean square error approximation $=0.046$. All items appear in the Appendix Table 3.

\subsubsection{R\&D intensity}

We measured our dependent variable, R\&D intensity, by dividing R\&D spending (in euros) by the number of employees (Barker and Mueller 2002; Le et al. 2006). Respondents were asked to report both values for fiscal year 2009. The literature suggests that using R\&D spending per employee as a measure of R\&D intensity is more stable than alternatives such as $R \& D$ spending divided by firm sales (Baysinger et al. 1991; Hill and Snell 1989). Mean R\&D intensity is 7525 euro per employee. We used the logarithm (ln) of R\&D intensity to minimize skewness.

\subsubsection{Firm growth}

We indicated firm growth with a two-item construct that measures sales and employee growth compared to competitors. Respondents were asked to rate the sales and employee growth of their own firm on a Likert-type scale, with a fivepoint response format anchored by "much worse than the competitors" to "much better than the competitors" (Wiklund and Shepherd 2003). Reliability analysis shows an acceptable internal consistency of the measure, with a Spearman-Brown coefficient of 0.75 , which is considered a robust indicator of the reliability of twoitem constructs (Bollen 1989; Eisinga et al. 2013).

\subsubsection{Control variables}

Because prior research stresses that industry can affect R\&D intensity, we controlled for four different manufacturing industries. We also controlled for firm age to address the liability of newness concerns as well as the potential for higher innovativeness in younger organizations (Stinchcombe 1965). We controlled for firm size, as larger firms may possess more slack that they can invest in R\&D (George 2005; Nohria and Gulati 1996). Firm size is measured by number of employees. We used the logarithm (ln) of number of employees to minimize skewness. On the CEO-level, we controlled for CEO age (measured in years) and CEO tenure (measured as the number of years since being appointed CEO). Research suggests that older CEOs are more conservative, follow low-growth strategies (Child 1974), and are resistant to change (Wiersema and Bantel 1992). Therefore, younger CEOs are likely to invest more in R\&D. CEOs with long tenures 


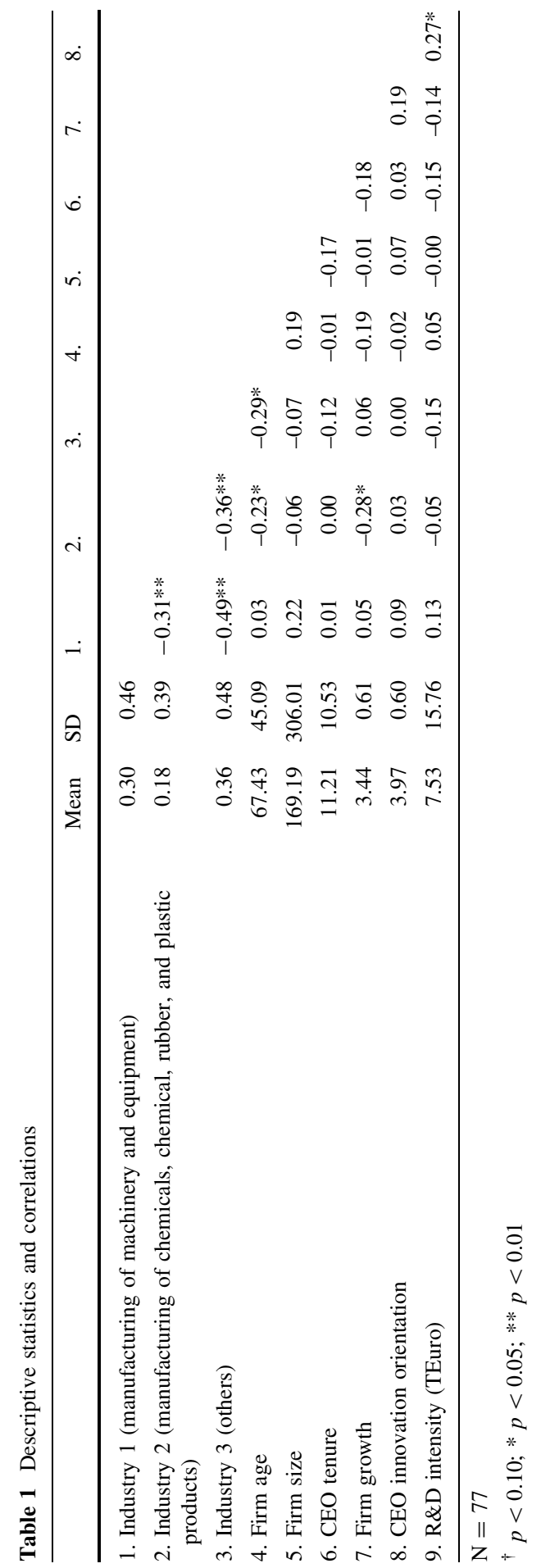




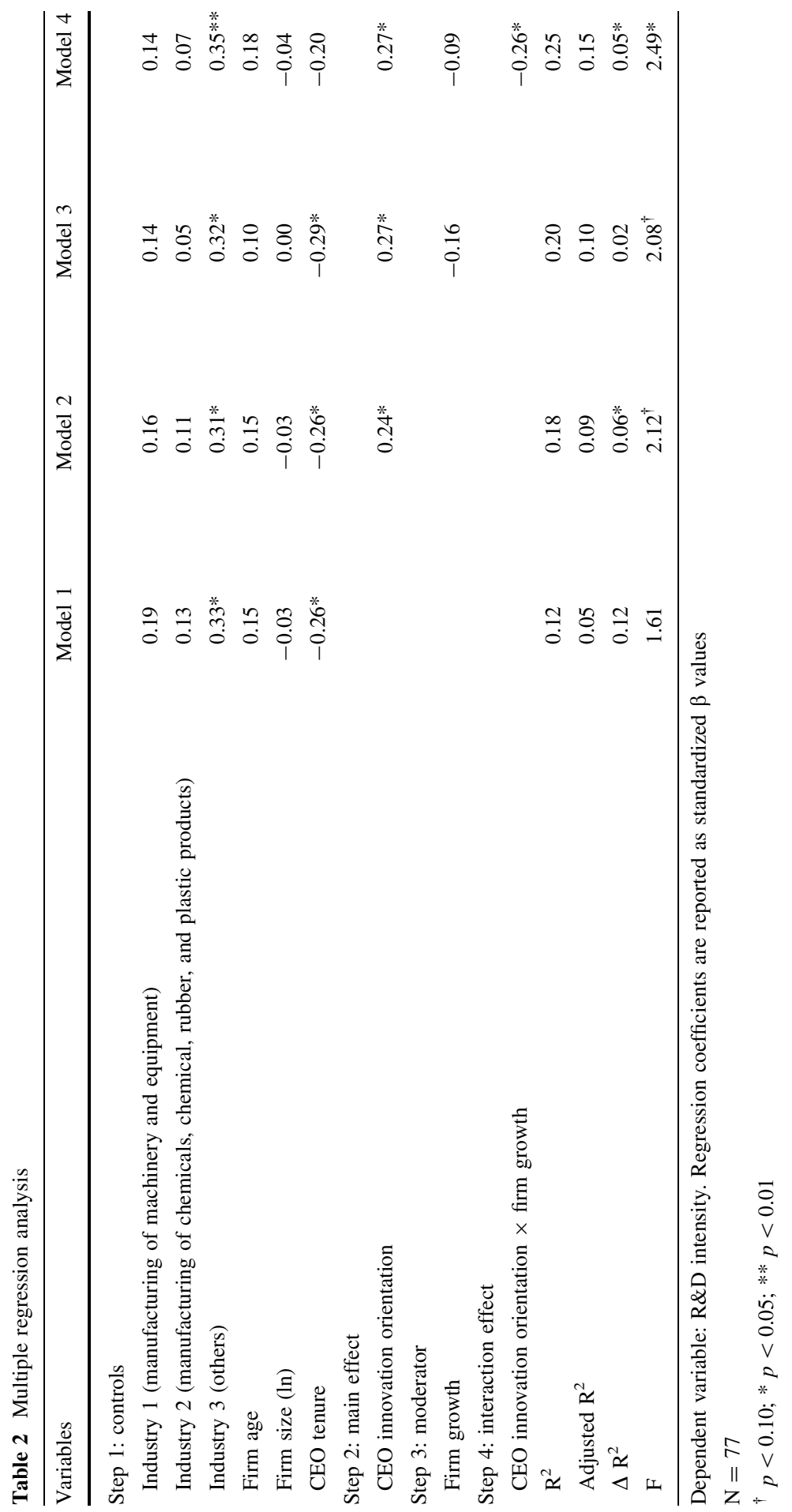


are less likely to pursue strategies of innovation through higher R\&D investments and more likely to focus on stability and efficiency (Barker and Mueller 2002). Because both measures have been found to be correlated, we only include CEO tenure in our analysis to reduce the problem of multicollinearity.

\section{Results}

The means, standard deviations, and zero-order correlations appear in Table 1. We tested our proposed hypotheses via OLS (ordinary least squares) regression analysis (Cohen et al. 2002). Results appear in Table 2.

In total, we tested four models. In Model 1, we entered three industries, firm size, firm age, and CEO tenure as controls. In Model 2, we entered the main effect, CEO innovation orientation, to test our first hypothesis. To test for moderation, we entered firm growth in Model 3. In Model 4, we entered the interaction effect between CEO innovation orientation and firm growth to measure its impact on R\&D intensity.

Model 1, which controls for industry effects, number of employees, firm age, and CEO tenure, indicates significant relationships. One of the control industries

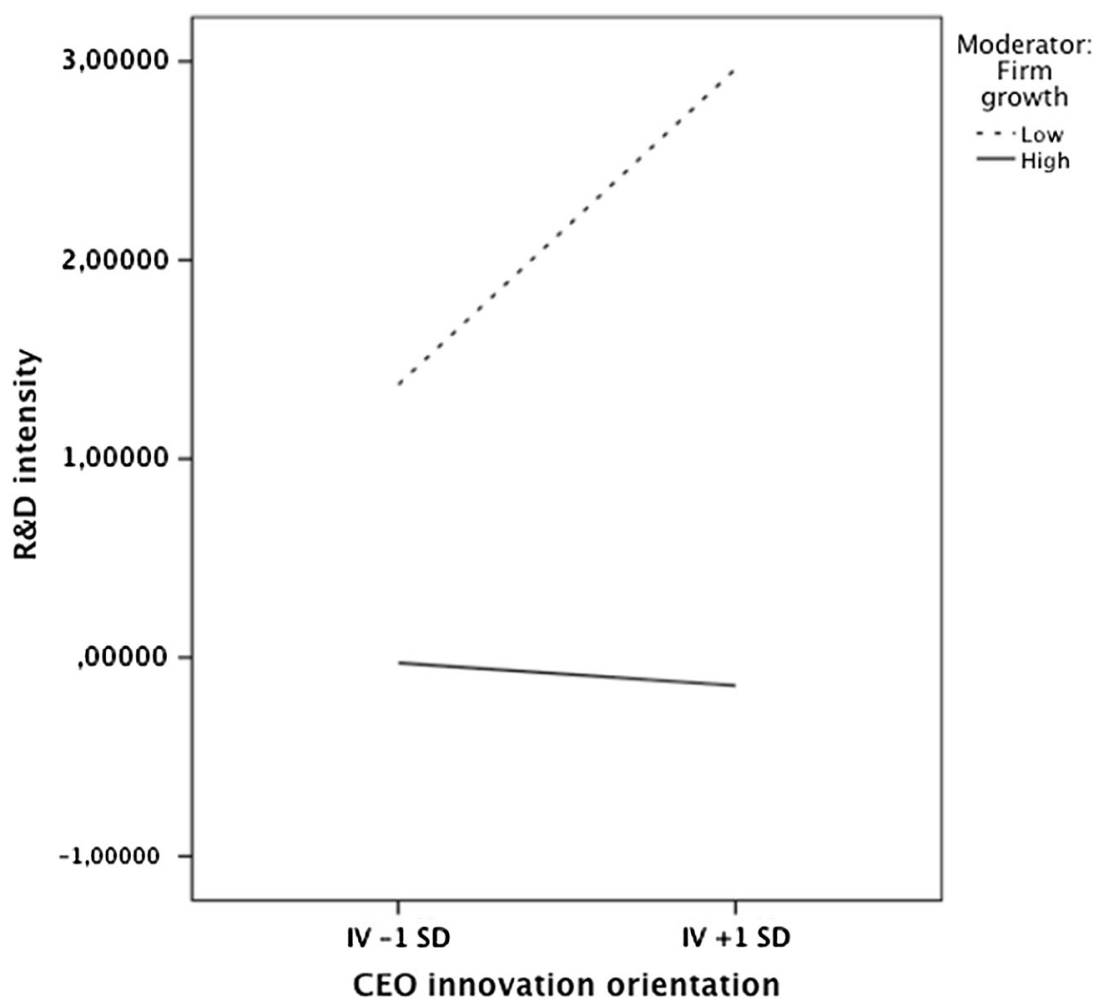

Fig. 1 Interaction effect $-\mathrm{CEO}$ innovation orientation $\times$ firm growth 
(industry 3: others) is positively significant $(\beta=0.33, p<0.05)$. Thus, $R \& D$ intensity of respondents from other manufacturing industries is significantly higher than that found in basic metal industries. CEO tenure is also significant and negatively related to $\mathrm{R} \& \mathrm{D}$ intensity $(\beta=-0.26, p<0.05)$, indicating that longer CEO tenure has a negative impact on $R \& D$ intensity.

To test Hypotheses 1, we entered all control variables and the independent variable in Model 2. Results show that CEO innovation orientation is positively related to $\mathrm{R} \& \mathrm{D}$ intensity $(\beta=0.24, p<0.05)$. The significant change in $\mathrm{R}^{2}$ $\left(\Delta \mathrm{R}^{2}=0.06, p<0.05\right)$ supports Hypothesis 1 .

In Model 3, we additionally entered firm growth as moderator. Results show that firm growth is not significantly related to $R \& D$ intensity $(\beta=-0.16$, n.s.).

To test Hypothesis 2, we added the interaction effect in Model 4. Hypothesis 2 predicts that CEO innovation orientation has a stronger effect on R\&D intensity if firm growth is low $(\beta=-0.26, p<0.05)$. The significant change in $\mathrm{R}^{2}$ $\left(\Delta \mathrm{R}^{2}=0.05, p<0.05\right)$ supports Hypothesis 2 .

To facilitate the interpretation of the moderation effect, we plotted the significant interaction in Fig. 1 (Aiken and West 1991; Cohen et al. 2002); as expected, low growth leads to higher R\&D intensity when CEO innovation orientation is high. Hence, Hypothesis 2 is supported. Figure 1 also shows that during periods of high growth, the level of CEO innovation orientation has no significant effect on R\&D intensity. The implications of our results are discussed in the next section.

To show the robustness of our results, we conducted multiple robustness checks. First, we tested for the statistical power of our model. Looking at our final model with nine predictors, a probability level of 0.05 , an observed $\mathrm{R}^{2}$ of 0.025 and our sample size of 77, we yielded an observed statistical power of 0.9325 , which is considered appropriate and compares favorably to prior studies (Mazen et al. 1987a, b). Accordingly, we do not believe that the sample size is a significant concern for our study. Second, we tested for curvilinear effects of CEO innovation orientation on firm growth. However, a curvilinear relationship was not significant. Third, we tested whether CEO innovation is a trait or a state by analyzing the effect of CEO age and CEO tenure on CEO innovation orientation. As both CEO age and CEO tenure show no significant effect on CEO innovation orientation, we believe that it is a trait, rather than a state. Lastly, we tested for reverse causality, as this could be present due to our cross-sectional design. Our results show that this was not a concern in this study (Davidson and Mackinnon 1983).

\section{Discussion}

Our results show that CEO innovation orientation plays an important role when investigating R\&D intensity in small and medium-sized firms. CEO innovation orientation has a direct positive effect on R\&D intensity, supporting Hypothesis 1. Introducing CEO innovation orientation as a behavioral intention of a CEO to engage in innovative activities to the nomological network of $R \& D$ research in small and medium-sized firms, we support upper echelon arguments and the importance of CEO characteristics and behavior (Chatterjee and Hambrick 2007; 
Hayward and Hambrick 1997; Miller and Toulouse 1986a) in the context of small and medium-sized firms. Although this effect has been found to be valid in large firms, empirical evidence on the importance of executives in small and mediumsized firms has been scarce.

Applying firm growth as a contingency factor that may explain variations in the level of R\&D intensity by interacting with CEO innovation orientation, the positive effect of CEO innovation orientation on R\&D intensity becomes stronger when firm growth is low. This supports the hypothesized interaction effect formulated in Hypothesis 2. It appears that firms with low growth benefit over-proportionally from CEOs with high innovation orientation, which can be an important advantage in improving firm performance (e.g., by introducing new products). Upper echelon theory suggests that with increasing job demands, CEO characteristics become stronger reflected in firm outcomes. Identifying low firm growth as an indicator of higher job demands, our results support upper echelon theory by showing that innovation orientation of the CEO becomes stronger reflected when firm growth is low. Additionally, in firms of high growth indicating low job demands, the effect of CEO innovation orientation is meaningless. Results indicate that high-growth small and medium-sized firms led by CEOs with low or high innovation orientation show nearly similar R\&D intensity. Furthermore, we support recent research on innovation orientation on the firm and TMT level by showing that CEO innovation orientation increases R\&D intensity in small and medium-sized firms.

Our results are also partially in accordance with arguments of threat rigidity theory. Generally, threats such as low firm growth result in rigidity such as more conservative strategies (Greve 2011). This is not the case in our study as highgrowth firms show conservative behaviors more than low growth firms. Our results support the argument that threats are more salient for risk-averse individuals than for risk-willing individuals. Because CEO innovation orientation describes intentions to engage in innovative activities, whose outcomes are uncertain and risky, CEOs with a high innovation orientation may be more risk willing than risk averse. Hence, CEOs with a high innovation orientation do not perceive low firm growth as a threat, and the effect of their innovation orientation becomes strongly reflected in the level of R\&D intensity.

Our study is the first to consider CEO innovation orientation as an individual CEO characteristic in the context of R\&D intensity in small and medium-sized firms. By applying upper echelon theory, we analyze the effect of CEO innovation orientation on R\&D intensity and contribute to recent literature that examines innovation orientation on the firm and TMT level (Kraiczy et al. 2014a; Narver et al. 2004) and to the literature that focuses on the importance of CEOs and their characteristics in small and medium-sized firms (e.g., Andries and Czarnitzki 2014; Wallace et al. 2010). As hierarchies are often flat and managerial discretion of the CEO is often high in small and medium-sized firms, our study supports the importance of the CEO. Analyzing $R \& D$ intensity from this firm-internal perspective, we extend research on antecedents of $R \& D$ intensity that have primarily focused on environmental factors. Furthermore, our study introduces firm growth as a moderator of the relationship between CEO innovation orientation and $\mathrm{R} \& \mathrm{D}$ intensity and allows us to reconcile the importance of the intentions of the 
CEO in times of low firm growth and the complex and contradictory findings in the literature on the direct effect of firm growth on R\&D intensity. Investigating R\&D intensity in small and medium-sized firms, we extend and contribute to recent research that focuses on R\&D in small and medium-sized firms (Falk 2012; Hall et al. 2009; Hölzl 2009; Ortega-Argilés et al. 2009).

\subsection{Limitations and future research}

We hope to encourage future research by discussing a few limitations of this study. First, solely including German small and medium-sized firms in the sample raises the question of generalizability. While there is no reason to believe that the effects of CEO characteristics are affected by country of origin, other researchers may want to replicate the findings in different cultural environments (Hofstede 2001) to identify potential country-specific influences (Miller et al. 2009).

Second, we used self-reported data from the CEO as the key informant. Obtaining comprehensive objective data from small and medium-sized firms, which are often not publicly traded and are reticent to report performance data to protect their privacy, is difficult and justifies subjective self-reported measures. Indeed, such measures are common in this line of research (Li and Tang 2010; Wallace et al. 2010), as self-assessments show high correlation with objective data (e.g., Dess et al. 1990; Ling and Kellermanns 2010). To further mitigate this concern, however, we substituted team-level data where available $(\mathrm{N}=51)$ and retested the investigated relationships. To justify the aggregation of multiple respondents to one TMT-level score, we used the $r_{\mathrm{wg}}$, which represents a measure of agreement among TMT members' perceptions (James et al. 1984, 1993); this measure exceeded 0.80 for all multi-level constructs. The findings and significances were consistent across approaches. Accordingly, key informant bias is not a significant concern in this study (Eddleston et al. 2008). We also suggest that focusing on TMT-level characteristics such as diversity (Barkema and Shvyrkov 2007; Knight et al. 1999; Talke et al. 2010) or power differences across organizational functions (Hambrick and Finkelstein 1987; Li and Tang 2010; Pitcher and Smith 2001) may be fruitful avenues of investigation in future research.

Third, we focused on innovation orientation as an individual CEO characteristic. Although we think this characteristic was a natural choice for our research question, Resick et al. (2009, p. 1365) state that "many important traits have yet to be examined, and the psychological mechanisms linking CEO personality to strategic influence and performance remain underexplored (Avolio et al. 2003; Boal and Hooijberg 2001)". We encourage future research to expand on the search for moderators by including additional personality traits (e.g., conscientiousness, neuroticism, agreeableness, extraversion, openness) (Barrick and Mount 1991).

Fourth, sample size may be a concern. Considering the observed effect size (Cohen 1988) and statistical power of 0.9325 , which compare favorably to many studies in the field of strategic management and management research (Mazen et al. 1987a, b), we do not believe power to be a problem in the present study (e.g., Barrick et al. 2007; Eddleston and Kellermanns 2007). In addition, we need to discuss the possibility of social desirability because such a bias may 
restrict the variance that is observed. However, we believe that social desirability of the CEO innovation orientation variable is not a significant concern in our study for multiple reasons. First, this utilized measure is established in the literature and social desirability concerns have not been identified as significant concerns in prior research. Second, a sub-sample showed high inter-rater reliability of the construct between the CEO and second respondents. As a second respondent would not have any social desirability in rating the $\mathrm{CEO}$, this mitigates the concern. Third, if there was a positive bias in the sample, this would bias the entire sample in the same direction, thus not affecting the observed relationships. Indeed, the mean value of 3.97 , on a 5 point Likert-type scale, does not necessarily suggest such a bias. Last, although the observed standard deviation was 0.60, and despite sample size concerns discussed above, the observed findings were strong and robust, further limiting the possibility of social desirability concerns in our study.

Fifth, we utilized a cross-sectional study design; hence, we cannot show causality. Additionally, a cross-sectional framework cannot catch the full dynamics of the R\&D investment decision. Hence, the generalization of our results should be made with caution. However, as moderation effects with dynamic variables are difficult to identify, using a cross-sectional design is disadvantageous for showing dynamic effects. Hence, by applying a longitudinal study design, results may become even stronger. A longitudinal study design would further improve our understanding of the relationship between CEO innovation orientation, firm growth, and R\&D intensity and is encouraged in future studies. Although using crosssectional data creates a risk of common method bias, tests suggests, that this is not a concern in our study (Podsakoff and Organ 1986). In particular, significant interaction effects cannot arise from common method variance as demonstrated by Monte Carlo study (Evans 1985). The cross-sectional design also gives rise to reverse causality concerns. Thus, to address potential endogeneity concerns [for a recent example see Walter et al. (2012)], we utilized two instrumental variables for the independent variable and moderator. Utilizing Stata and IVENDOG and IVREG (Baum et al. 2002) neither the resulting Wu-Hausman $F$-test nor the Durbin-WuHausman test were significant, suggesting that we can report our estimates, as they are not biased and reverse causality does not appear to be a concern (Davidson and Mackinnon 1983).

Last, we focus on the manufacturing sector to ensure that the participating firms engage in R\&D. Therefore, future researchers need to replicate the findings in other sectors to assess the generalizability of results.

Future research may also include CEO compensation as a moderating effect. High-paid CEOs may be more risk willing during a downturn or crisis compared to low-paid CEOs.

\section{Conclusion}

This study analyzes the relationship between CEO innovation orientation, firm growth, and R\&D intensity. Specifically, we show that CEO innovation orientation 
has a positive impact on R\&D intensity. Additionally, in small and medium-sized firms with low growth, CEO innovation orientation has a stronger positive effect on R\&D intensity. Specifically, our results support upper echelon theory, which describes executives as having a strong impact on strategic outcomes.

\section{Appendix}

See Table 3.

Table 3 Scale items and reliabilities

\begin{tabular}{|c|c|c|}
\hline Construct & Items & $\begin{array}{l}\text { Cronbach's } \\
\text { Alpha }\end{array}$ \\
\hline \multicolumn{3}{|l|}{$\begin{array}{l}\text { Independent } \\
\text { variable }\end{array}$} \\
\hline Firm growth & $\begin{array}{l}\text { Please rate your company regarding the following key performance } \\
\text { indicators in comparison to other companies in your industry! } \\
\text { Employee growth } \\
\text { Sales growth }\end{array}$ & 0.74 \\
\hline $\begin{array}{l}\text { CEO innovation } \\
\text { orientation }\end{array}$ & $\begin{array}{l}\text { I encourage creativity } \\
\text { I respect the ability of team members to function creatively } \\
\text { I try to be flexible and continually adapt to change } \\
\text { I'm open and responsive to change } \\
\text { I try to assist in developing new ideas } \\
\text { I want to provide adequate resources to innovation } \\
\text { I want to provide adequate time to pursue creative ideas } \\
\text { I publicly recognize those who are innovative }\end{array}$ & 0.91 \\
\hline
\end{tabular}

\section{References}

Acs ZJ, Carlsson B, Karlsson C (1999) The linkages among entrepreneurship, SMEs and the macroeconomy. In: Acs ZJ, Carlsson B, Karlsson C (eds) Entrepreneurship, small and medium-sized enterprises and the macroeconomy. Cambridge University Press, Cambridge, pp 3-42

Aghion P, Howitt P (1998) Endogenous growth theory. MIT Press, Cambridge

Aghion P, Bond S, Klemm A, Marinescu I (2004) Technology and financial structure: are innovative firms different? J Eur Econ Assoc 2:277-288

Aghion P, Bloom N, Blundell R, Griffith R, Howitt P (2005) Competition and innovation: an inverted-U relationship. Quart J Econ 120:701-728

Ahmadjian CL, Robinson P (2001) Safety in numbers: downsizing and the deinstitutionalization of permanent employment in Japan. Admin Sci Quart 46:622-654

Aiken LS, West SG (1991) Multiple regression: testing and interpreting interactions. Sage Publications, Newbury Park

Anand J, Singh H (1997) Asset redeployment, acquisitions and corporate strategy in declining industries. Strateg Manag J 18:99-118

Andries P, Czarnitzki D (2014) Small firm innovation performance and employee involvement. Small Bus Econ 43:21-38 
Antonelli C (1989) A failure-inducement model of research and development expenditure: Italian evidence from the early 1980s. J Econ Behav Organ 12:159-180

Arvanitis S, Woerter M (2011) Firm characteristics and the cyclicality of R\&D investments. KOF Working Papers No. 277, Zurich

Avolio BJ, Sosik JJ, Jung DI, Berson Y (2003) Leadership models, methods, and applications. In: Borman WC, Ilgen DR, Klimoski RJ (eds) Handbook of psychology. Wiley, Hoboken, pp 277-307

Barkema HG, Shvyrkov O (2007) Does top management team diversity promote or hamper foreign expansion? Strateg Manag J 28:663-680

Barker VL, Mueller GC (2002) CEO characteristics and firm R\&D spending. Manag Sci 48:782-801

Barlevy G (2007) On the cyclicality of research and development. Am Econ Rev 97:1131-1164

Barrick MR, Mount MK (1991) The big five personality dimensions and job performance: a meta analysis. Pers Psychol 44:1-26

Barrick MR, Bradley BH, Kristof-Brown AL, Colbert AE (2007) The moderating role of top management team interdependence: implications for real teams and working groups. Acad Manag J 50:544-557

Baum CF, Schaffer ME, Stillman S (2002) IVENDOG: Stata module to calculate Durbin-Wu-Hausman endogeneity test after ivreg. Boston College Department of Economics, Boston

Baysinger BD, Hoskisson RE (1989) Diversification strategy and R\&D intensity in multiproduct firms. Acad Manag J 32:310-332

Baysinger BD, Kosnik RD, Turk TA (1991) Effects of board and ownership structure on corporate R\&D strategy. Acad Manag J 34:205-214

Bennedsen M, Wolfenzon D (2000) The balance of power in closely held corporations. J Financ Econ 58:113-139

Boal KB, Hooijberg R (2001) Strategic leadership research: moving on. Leadersh Q 11:515-549

Bollen KA (1989) Structural equations with latent variables. Wiley, New York

Brunninge O, Nordqvist M, Wiklund J (2007) Corporate governance and strategic change in SMEs: the effects of ownership, board composition and top management teams. Small Bus Econ 29:295-308

Calantone RJ, Garcia R, Dröge C (2003) The effects of environmental turbulence on new product development strategy planning. J Prod Innov Manag 20:90-103

Campello M, Graham JR, Harvey CR (2010) The real effects of financial constraints: evidence from a financial crisis. J Financ Econ 97:470-487

Carpenter MA, Geletkanycz MA, Sanders WG (2004) Upper echelons research revisited: antecedents, elements, and consequences of top management team composition. J Manag 30:749-778

Chatterjee A, Hambrick DC (2007) It's all about me: narcissistic chief executive officers and their effects on company strategy and performance. Admin Sci Quart 52:351-386

Chen W-R, Miller KD (2007) Situational and institutional determinants of firms' R\&D search intensity. Strateg Manag J 28:369-381

Child J (1974) Managerial and organizational factors associated with company performance. J Manag Stud 11:175-189

Coad A, Rao R (2009) Firm growth and R\&D expenditure. Econ Innov New Tech 19:127-145

Cohen J (1988) Statistical power analysis for behavioral sciences. Lawrence Erlbaum Associates, Hillsdale

Cohen J, Cohen P, West SG, Aiken LS (2002) Applied multiple regression/correlation analysis for the behavioral sciences. Lawrence Erlbaum Associates, Mahwah

Crossland C, Hambrick DC (2007) How national systems differ in their constraints on corporate executives: a study of CEO effects in three countries. Strateg Manag J 28:767-789

Daellenbach US, McCarthy AM, Schoenecker TS (1999) Commitment to innovation: the impact of top management team characteristics. R\&D Manag 29:199-208

Davidson R, Mackinnon JG (1983) Estimation and interference in econometrics. Oxford University Press, New York

Dess GG, Ireland RD, Hitt MA (1990) Industry effects and strategic management research. J Manag 16:7-27

Eddleston KA, Kellermanns FW (2007) Destructive and productive family relationships: a stewardship theory perspective. J Bus Ventur 22:545-565

Eddleston KA, Kellermanns FW, Sarathy R (2008) Resource configuration in family firms: linking resources, strategic planning and technological opportunities to performance. J Manag Stud 45:26-50

Eisinga R, Grotenhuis M, Pelzer B (2013) The reliability of a two-item scale: Pearson, Cronbach, or Spearman-Brown? Int J Public Health 58:637-642 
Ettlie JE (1998) R\&D and global manufacturing performance. Manag Sci 44:1-11

European Commission (2010) The 2010 EU industrial R\&D investment scoreboard. Joint Research Centre and Directorate General for Research, Luxembourg

European Commission (2013) Innovation Union Scoreboard 2013. doi:10.2769/72530

Evans MG (1985) A Monte Carlo study of the effects of correlated method variance in moderated multiple regression analysis. Organ Behav Hum Decis Process 36:305-323

Falk M (2012) Quantile estimates of the impact of R\&D intensity on firm performance. Small Bus Econ 39:19-37

Felekoglu B, Moultrie J (2014) Top management involvement in new product development: a review and synthesis. J Prod Innov Manag 31:159-175

Filatotchev I, Piesse J (2009) R\&D, internationalization and growth of newly listed firms: European evidence. J Int Bus Stud 40:1260-1276

Filippetti A, Archibugi D (2011) Innovation in times of crisis: national systems of innovation, structure, and demand. Res Pol 40:179-192

Ford RH (1988) Outside directors and the privately-owned firm: are they necessary? Entrep Theory Pract 13:49-57

García-Manjón JV, Romero-Merino ME (2012) Research, development, and firm growth. Empirical evidence from European top R\&D spending firms. Res Pol 41:1084-1092

George G (2005) Slack resources and the performance of privately held firms. Acad Manag J 48:661-676

German Federal Ministry of Economics and Technology (2013) Policy for small and medium-sized businesses. Federal Ministry of Economics and Technology. http://www.bmwi.de/EN/Topics/ Economy/small-business-policy.html. Accessed 05 Nov 2013

Geroski PA, Gregg P (1997) Coping with recession. Cambridge University Press, Cambridge

Gilley KM, Walters BA, Olson BJ (2002) Top management team risk taking propensities and firm performance: direct and moderating effects. J Bus Strateg 19:95-114

Greve HR (2003) A behavioral theory of R\&D expenditures and innovations: evidence from shipbuilding. Acad Manag J 46:685-702

Greve HR (2011) Positional rigidity: low performance and resource acquisition in large and small firms. Strateg Manag J 32:103-114

Guellec D, Ioannidis E (1999) Causes of fluctuations in R\&D expenditures: a quantitative analysis, vol 29. OECD, Paris

Hair JF, Black WC, Babin BJ, Anderson RE (2010) Multivariate data analysis. Prentice Hall, Upper Saddle River

Hall B, Lotti F, Mairesse J (2009) Innovation and productivity in SMEs: empirical evidence for Italy. Small Bus Econ 33:13-33

Hambrick DC (2005) Upper echelons theory: Origins, twists and turns, and lessons learned. In: Smith KG, Hitt MA (eds) Great minds in management: The process of theory development. Oxford University Press, New York, pp 109-127

Hambrick DC (2007) Upper echelons theory: an update. Acad Manag Rev 32:334-343

Hambrick DC, Finkelstein S (1987) Managerial discretion: a bridge between polar views of organizational outcomes. Res Organ Behav 9:369-406

Hambrick DC, Mason PA (1984) Upper echelons: the organization as a reflection of its top managers. Acad Manag Rev 9:193-206

Hambrick DC, Finkelstein S, Mooney AC (2005) Executive job demands: new insights for explaining strategic decisions and leader behaviors. Acad Manag Rev 30:472-491

Hayward MLA, Hambrick DC (1997) Explaining the premiums paid for large acquisitions: evidence of CEO hubris. Admin Sci Quart 42:103-127

Hill CWL, Snell SA (1989) Effects of ownership structure and control on corporate productivity. Acad Manag J 32:25-46

Himmelberg CP, Petersen BC (1994) R\&D and internal finance: a panel study of small firms in high-tech industries. Rev Econ Stat 76:38-51

Hitt MA, Tyler BB (1991) Strategic decision models: integrating different perspectives. Strateg Manag J 12:327-351

Ho Yew K, Tjahjapranata M, Yap Chee M (2006) Size, leverage, concentration, and R\&D investment in generating growth opportunities. J Bus 79:851-876

Hofstede G (2001) Culture's consequences: comparing values, behaviors, institutions, and organizations across nations. Sage Publications, Thousand Oaks 
Hölzl W (2009) Is the R\&D behaviour of fast-growing SMEs different? Evidence from CIS III data for 16 countries. Small Bus Econ 33:59-75

Hoskisson RE, Hitt MA (1988) Strategic control systems and relative R\&D investment in large multiproduct firms. Strateg Manag J 9:605-621

Hülsbeck M, Lehmann EE, Weiß D, Wirsching K (2012) Innovationsverhalten in Familienunternehmen. Z Betriebswirtschaft 82:71-91

Hundley G, Jacobson CK, Park SH (1996) Effects of profitability and liquidity on R\&D intensity: Japanese and U.S. companies compared. Acad Manag J 39:1659-1674

Hurley RF, Hult GTM (1998) Innovation, market orientation, and organizational learning: an integration and empirical examination. J Mark 62:42-54

Huse M (2000) Boards of directors in SMEs: a review and research agenda. Entrep Reg Dev 12:271-290

James LR, Demaree RG, Wolf G (1984) Estimating within-group interrater reliability with and without response bias. J Appl Psychol 69:85-98

James LR, Demaree RG, Wolf G (1993) rwg: an assessment of within-group interrater agreement. J Appl Psychol 78:306-309

Kamien MI, Schwartz NL (1982) Market structure and innovation. Cambridge University Press, Cambridge

Kanuk L, Berenson C (1975) Mail surveys and response rates: a literature review. J Mark Res 12:440-453

Keh HT, Foo MD, Lim BC (2002) Opportunity evaluation under risky conditions: the cognitive processes of entrepreneurs. Entrep Theory Pract 27:125-148

Knight D, Pearce CL, Smith KG, Olian JD, Sims HP, Smith KA, Flood P (1999) Top management team diversity, group process, and strategic consensus. Strateg Manag J 20:445-465

Kraiczy ND, Hack A, Kellermanns FW (2014a) New product portfolio performance in family firms. J Bus Res 67:1065-1073

Kraiczy ND, Hack A, Kellermanns FW (2014b) The relationship between top management team innovation orientation and firm growth: the mediating role of firm innovativeness. Int J Innov Manag. doi:10.1142/S136391961550005X

Kraiczy ND, Hack A, Kellermanns FW (2014c) What makes a family firm innovative? CEO risk-taking propensity and the organizational context of family firms. J Prod Innov Manag. doi:10.1111/jpim. 12203

Kumar N, Stern LW, Anderson JC (1993) Conducting interorganizational research using key informants. Acad Manag J 36:1633-1651

Lawrence BS (1997) The black box of organizational demography. Organ Sci 8:1-22

Le SA, Walters B, Kroll M (2006) The moderating effects of external monitors on the relationship between R\&D spending and firm performance. J Bus Res 59:278-287

Lee PM, O’Neill HM (2003) Ownership structures and R\&D investments of US and Japanese firms: agency and stewardship perspectives. Acad Manag J 46:212-225

Li J, Tang YI (2010) CEO hubris and firm risk taking in China: the moderating role of managerial discretion. Acad Manag J 53:45-68

Ling Y, Kellermanns FW (2010) The effects of family firm specific sources of TMT diversity: the moderating role of information exchange frequency. J Manag Stud 47:322-344

Lotti F, Santarelli E, Vivarelli M (2009) Defending Gibrat's law as a long-run regularity. Small Bus Econ $32: 31-44$

Mairesse J, Hall B, Branstetter L, Crepon B (1999) Does cash flow cause investment and R\&D? An exploration using panel data for French, Japanese, and United States scientific firms. In: Audretsch DB, Thurik R (eds) Innovation, industry evolution, and employment. Cambridge University Press, Cambridge, pp 129-156

Mazen AM, Graf LA, Kellogg CE, Hemmasi M (1987a) Statistical power in contemporary management research. Acad Manag J 30:369-380

Mazen AM, Hemmasi M, Lewis MF (1987b) Assessment of statistical power in contemporary strategy research. Strateg Manag J 8:403-410

Miller D, Dröge C (1986) Psychological and traditional determinants of structure. Admin Sci Quart 31:539-560

Miller D, Toulouse J-M (1986a) Chief executive personality and corporate strategy and structure in small firms. Manag Sci 32:1389-1409

Miller D, Toulouse J-M (1986b) Strategy, structure, CEO personality and performance in small firms. Am J Small Bus 10:47-62 
Miller D, Lee J, Chang S, Le Breton-Miller I (2009) Filling the institutional void: the social behavior and performance of family vs non-family technology firms in emerging markets. J Int Bus Stud 40:802-817

Mudambi R, Swift T (2011) Proactive R\&D management and firm growth: a punctuated equilibrium model. Res Pol 40:429-440

Muñoz-Bullón F, Sanchez-Bueno MJ (2011) The impact of family involvement on the R\&D intensity of publicly traded firms. Fam Bus Rev 24:62-70

Nadkarni S, Herrmann P (2010) CEO personality, strategic flexibility, and firm performance: the case of the indian business process outsourcing industry. Acad Manag J 53:1050-1073

Narver JC, Slater SF, MacLachlan DL (2004) Responsive and proactive market orientation and newproduct success. J Prod Innov Manag 21:334-347

Nohria N, Gulati R (1996) Is slack good or bad for innovation? Acad Manag J 39:1245-1264

Nunes PM, Serrasqueiro Z, Leitão J (2012) Is there a linear relationship between R\&D intensity and growth? Empirical evidence of non-high-tech vs. high-tech SMEs. Res Pol 41:36-53

Oppenheim AN (1966) Questionnaire design, interviewing and attitude measurement. Free Press, New York

Ortega-Argilés R, Vivarelli M, Voigt P (2009) R\&D in SMEs: a paradox? Small Bus Econ 33:3-11

Pitcher P, Smith AD (2001) Top management team heterogeneity: personality, power, and proxies. Organ Sci $12: 1-18$

Podsakoff PM, Organ DW (1986) Self-reports in organizational research: problems and prospects. J Manag 12:531-544

Rauch A, Wiklund J, Lumpkin GT, Frese M (2009) Entrepreneurial orientation and business performance: an assessment of past research and suggestions for the future. Entrep Theory Pract 33:761-787

Resick CJ, Weingarden SM, Whitman DS, Hiller NJ (2009) The bright-side and the dark-side of CEO personality: examining core self-evaluations, narcissism, transformational leadership, and strategic influence. J Appl Psychol 94:1365-1381

Rosenbusch N, Brinckmann J, Bausch A (2011) Is innovation always beneficial? A meta-analysis of the relationship between innovation and performance in SMEs. J Bus Ventur 26:441-457

Scherer FM (1984) Innovation and growth: Schumpeterian perspectives. MIT Press Books, Cambridge

Schumpeter JA (1934) The theory of economic development. Harvard University Press, Cambridge

Scott SG, Bruce RA (1994) Determinants of innovative behavior: a path model of individual innovation in the workplace. Acad Manag J 37:580-607

Seidler J (1974) On using informants: a technique for collecting quantitative data and controlling measurement error in organization analysis. Am Sociol Rev 39:816-831

Siegel SM, Kaemmerer WF (1978) Measuring the perceived support for innovation in organizations. J Appl Psychol 63:553-562

Souitaris V (2001) Strategic influences of technological innovation in Greece. $\mathrm{Br} \mathrm{J}$ Manag 12:131-147

Staw BM, Sandelands LE, Dutton JE (1981) Threat rigidity effects in organizational behavior: a multilevel analysis. Admin Sci Quart 26:501-524

Stinchcombe AL (1965) Social structure and organizations. In: March JG (ed) Handbook of organizations. Rand McNally \& Company, Chicago, pp 142-193

Talke K, Salomo S, Rost K (2010) How top management team diversity affects innovativeness and performance via the strategic choice to focus on innovation fields. Res Pol 39:907-918

Thompson P (2001) The microeconomics of an R\&D-based model of endogenous growth. J Econ Growth 6:263-283

Upton N, Teal EJ, Felan JT (2001) Strategic and business planning practices of fast growth family firms. J Small Bus Manag 39:60-72

Wallace JC, Little LM, Hill AD, Ridge JW (2010) CEO regulatory foci, environmental dynamism, and small firm performance. J Small Bus Manag 48:580-604

Walter J, Kellermanns FW, Lechner C (2012) Decision making within and between organizations: rationality, politics and alliance performance. J Manag 38:1582-1610

Wiersema MF, Bantel KA (1992) Top management team demography and corporate strategic change. Acad Manag J 35:91-121

Wiklund J, Shepherd DA (2003) Knowledge-based resources, entrepreneurial orientation, and the performance of small and medium-sized businesses. Strateg Manag J 24:1307-1314 
Wright M, Kellermanns FW (2011) Family firms: a research agenda and publication guide. J Fam Bus Strateg 2:187-198

Zahra SA, Hayton JC, Salvato C (2004) Entrepreneurship in family vs. non-family firms: a resource-based analysis of the effect of organizational culture. Entrep Theory Pract 28:363-381 